\title{
Crop Diversification Remedy on Agrarian Distress
}

\author{
P.S. Deshmukh ${ }^{*}$, R.G. Deshmukh ${ }^{2}$, K.R. Bhaskar ${ }^{3}$ \\ Dr. P.D.K.V. Akola, India \\ *Corresponding author:
}

\begin{abstract}
A B S T R A C T
Keywords

Crop,

Diversification, Herfindahl index, Agrarian

Article Info

Accepted:

24 November 2018

Available Online:

10 December 2018

The present study was based on secondary data collected from different government publications. The data covered a period of 13 years i.e. 2003-04 to 2015-16. The crops which covered more than 80 per cent of the total cropped area considered for study. In order to study the extent of crop diversification Herfindahl index has been used in order to study the Economics of crop diversification, for identification of advantageous crop land concentration ratio in selected tehsils with comparative advantage was computed of selected years. Amravati district of selected tahsil show diversification was observed. Udid and gram found to be more advantageous crop in Amravati tahsil. In Daryapur and Chandur Rly. tahsils gram was found more advantageous crop in Amravati district.
\end{abstract}

\section{Introduction}

The rural economy of Amravati division is basically a crop economy. Through contribution of other sub-sector like Horticulture, Forestry, has increased overtime, the cropping sector remains the major contributors to the domestic product.

With the development of agriculture, cropping patter has been changed to cope with the changing scenario and to meet the everchanging demands of growing population. Crop diversification is a strategy to maximize the use of land, water and other resources and for the overall Agricultural development in the country. It provides the farmers with viable options to grow different crops on their land.
The diversification in agriculture is also practiced with a view to avoid risk and uncertainty due to climatic and biological vagaries. It minimizes the adverse effects of the current system of crop specialization and monoculture for better resource use, nutrient recycling, reduction of risk and uncertainty and better soil conditions. It also provides better economic viability with value added products and improvement of ecology.

\section{Objectives of study}

1. To examine the extent of diversification in selected tahsils over a period of time.

2. To identify the advantageous crops in selected tahsils. 


\section{Materials and Methods}

\section{Selection of area}

The study has been confined to the Amravati district of Vidarbha region of Maharashtra State. Four tahsils were selected randomly Amravati, Daryapur, Morshi, Chandur Rly. The study is based on data for the period 2003-04 to 2015-16.

\section{Analysis for extent of crop diversification: Herfindahl Index (HI)}

The extent of crop diversification was studied by using Herfindahl index. This index was calculated for time period from 2003-04 to 2015-16 for selected tahsil of Amravati district.

\section{Herfindahl Index (HI)}

Herfindahl index (HI) was computed by taking sum of squares of acreage proportion of each crop to the total cropped area.

$$
\mathrm{HI}=\underset{\mathrm{i}=1}{\mathrm{~N}} \mathrm{Pi}^{2}
$$

Where,

$\mathrm{N}=$ The total number of crops

$\mathrm{Pi}=$ Proportion of acreage under $\mathrm{i}^{\text {th }}$ crop to total cropped area

The value of $\mathrm{HI}$ is bounded by zero (perfect diversification) and one (complete specification). The value of $\mathrm{HI}$ approaches zero as ' $\mathrm{N}$ ' becomes large and takes value one when only one crop is cultivated.

\section{Analysis of identification of advantageous crop}

In order to identify the advantageous crop, land concentration ratio in selected tahsils with comparative advantages was computed for selected period i.e. from 2003-04 to 201516. The comparative advantage is here approximated by the per ha. gross revenue of each crop relative to the average revenue of the remaining crops (Takashi Kurosaki, 2003).

Land concentration ratio

$=\frac{\text { Gross revenue of each crop }}{\text { Average revenue of remaining crop }}$

\section{Results and Discussion}

The data collected from different sources for this investigation was analysed as per methodology outlined in previous chapter and the results of the analysis are presented in this chapter under following headings.

1. Extent of diversification.

2. Identification of advantageous crops.

\section{Extent of diversification}

The approach used in this study for crop diversification is to utilize a variety of measure of crop diversification, which connects the extent of dispersion and concentration of activities in a given time and space. The extent of crop diversification was studied by using Herfindahl index. This index was calculated for time period from 2003-04 to 2015-16 for each tahsil of Amravati division.

Measurement of crop diversification in selected tahsils of Amravati district are presented in Table 1.

The Table 1 shows that in all tahsils of Amravati district, the diversification index varied from 0.1999 (corresponding to Daryapur tahsil during the year 2007-08) and 0.4709 (corresponding to Amravati during the year 2015-16). Which shows diversification took place in selected tahsils of Amravati district. 
Identification of advantageous crops

In order to identify the advantageous crops, land concentration ratios in selected tahsils with comparative advantages were computed for selected period i.e. from 2003-04 to 2015-

Table.1 Measurement of crop diversification in selected tahsil of Amravati district

\begin{tabular}{|c|c|c|c|c|}
\hline Year & Amravati & Daryapur & Morshi & Chandur Rly. \\
\hline $\mathbf{2 0 0 3 - 0 4}$ & 0.2179 & 0.2404 & 0.2424 & 0.3389 \\
\hline $\mathbf{2 0 0 7 - 0 8}$ & 0.2265 & 0.1999 & 0.2279 & 0.2366 \\
\hline $\mathbf{2 0 1 1 - 1 2}$ & 0.3641 & 0.2229 & 0.2679 & 0.2641 \\
\hline $\mathbf{2 0 1 5 - 1 6}$ & 0.4709 & 0.2011 & 0.3209 & 0.4011 \\
\hline
\end{tabular}

Table.2.1 Land concentration ratios of major crops in Amravati tehsil

\begin{tabular}{|c|c|c|c|c|c|c|c|c|}
\hline Year & Kh. Jowar & Tur & Mung & Udid & Cotton & Soybean & Wheat & Gram \\
\hline $\mathbf{2 0 0 3 - 0 4}$ & 0.79 & 1.72 & 0.74 & 0.28 & 0.94 & 1.54 & 1.14 & 1.03 \\
\hline $\mathbf{2 0 0 7 - 0 8}$ & 0.43 & 1.27 & 0.40 & 0.46 & 1.09 & 1.48 & 2.05 & 1.13 \\
\hline $\mathbf{2 0 1 1 - 1 2}$ & 0.47 & 1.38 & 0.50 & 0.64 & 0.97 & 1.35 & 1.19 & 1.70 \\
\hline $\mathbf{2 0 1 5 - 1 6}$ & 0.21 & 1.03 & 0.55 & 0.89 & 1.52 & 0.81 & 1.28 & 1.96 \\
\hline
\end{tabular}

Table.2.2 Land concentration ratios of major crops in Daryapur tehsil

\begin{tabular}{|c|c|c|c|c|c|c|c|c|}
\hline Year & Kh. Jowar & Tur & Mung & Udid & Cotton & Soybean & Wheat & Gram \\
\hline $\mathbf{2 0 0 3 - 0 4}$ & 0.83 & 1.44 & 0.32 & 1.07 & 1.06 & 1.50 & 0.75 & 1.15 \\
\hline $\mathbf{2 0 0 7 - 0 8}$ & 0.64 & 1.05 & 0.54 & 0.52 & 1.76 & 1.24 & 1.06 & 1.36 \\
\hline $\mathbf{2 0 1 1 - 1 2}$ & 0.55 & 1.47 & 0.96 & 0.78 & 1.05 & 0.89 & 0.83 & 1.57 \\
\hline $\mathbf{2 0 1 5 - 1 6}$ & 0.17 & 2.33 & 0.77 & 0.24 & 2.57 & 0.33 & 0.64 & 1.70 \\
\hline
\end{tabular}

Table.2.3 Land concentration ratios of major crops in Morshi tehsil

\begin{tabular}{|c|c|c|c|c|c|c|c|c|}
\hline Year & Kh. Jowar & Tur & Mung & Udid & Cotton & Soybean & Wheat & Gram \\
\hline $\mathbf{2 0 0 3 - 0 4}$ & 0.65 & 1.42 & 0.77 & 0.88 & 0.91 & 1.30 & 1.00 & 1.11 \\
\hline $\mathbf{2 0 0 7 - 0 8}$ & 0.61 & 0.88 & 0.49 & 0.55 & 1.04 & 1.16 & 2.04 & 1.47 \\
\hline $\mathbf{2 0 1 1 - 1 2}$ & 0.47 & 1.18 & 0.68 & 0.76 & 0.91 & 0.79 & 1.16 & 2.29 \\
\hline $\mathbf{2 0 1 5 - 1 6}$ & 0.36 & 1.73 & 0.35 & 0.31 & 2.90 & 0.45 & 0.72 & 2.92 \\
\hline
\end{tabular}

Table.2.4 Land concentration ratios of major crops in Chandur Rly. Tehsil

\begin{tabular}{|c|c|c|c|c|c|c|c|c|}
\hline Year & Kh. Jowar & Tur & Mung & Udid & Cotton & Soybean & Wheat & Gram \\
\hline $\mathbf{2 0 0 3 - 0 4}$ & 0.82 & 1.78 & 0.25 & 0.06 & 1.68 & 1.60 & 1.11 & 1.08 \\
\hline $\mathbf{2 0 0 7 - 0 8}$ & 0.57 & 1.26 & 0.45 & 0.23 & 1.24 & 0.93 & 2.32 & 1.36 \\
\hline $\mathbf{2 0 1 1 - 1 2}$ & 0.63 & 1.32 & 0.58 & 0.27 & 1.34 & 1.27 & 1.43 & 1.34 \\
\hline $\mathbf{2 0 1 5 - 1 6}$ & 0.38 & 1.74 & 0.56 & 0.22 & 1.68 & 1.27 & 0.98 & 1.48 \\
\hline
\end{tabular}


Identification of advantageous crops in Amravati district

To identify advantageous crops in selected tahsils of Amravati district, land concentration ratios were computed and presented in table 2.1 to 2.4 .

From table 2.1, it was seen that the land concentration ratio of Udid and Gram showed increasing trend over a period of time. It means that Udid, Gram is more advantageous crop over kh.jowar, Tur, Mung, Cotton, Soybean and Wheat.

Similar results were found by Takshi kurosaki (2003) revealed that area under the crop is being concentrated in tahsils that have comparative advantage in producing a crop over other crops.

It was observed from table 2.2, that the land concentration ratios of gram shows increasing trend from 2003-04 to 2015-16. It means that Gram were more advantageous crops over Kh.jowar, Tur, Mung, Udid, Cotton, Soybean and Wheat. Results are in conformity with study made by Korra (2016) regarding Land concentration ratio of Cotton showed increasing trend over a period of study in Amravati district. It means cotton was most advantageous crop in Amravati district.

Table 2.3 revealed that over a period of time, land concentration ratios of Gram in Morshi tahsil shows increasing trend. Which denotes Gram was more advantageous crop over Kh.jowar, Tur, Mung, Udid, Cotton, Soybean and Wheat.

Table 2.4 revealed that over a period of time, land concentration ratios of Gram in Chandur Rly. Tahsil shows increasing trend. Which denotes Gram was more advantageous crop over Kh.jowar, Tur, Mung, Udid, Cotton, Soyb
In conclusion,

1. The result of Herfindahl index denotes that Akola district of selected tahsil show diversification farmers followed mixed of cropping to avoiding production risk.

2. Udid and gram found to be more advantageous crop in Amravati tahsil. In Daryapur and Chandur Rly. tahsils gram was found more advantageous crop.

\section{Policy implication}

Advantageous crop and land concentration ratio are the major sources to overcome agrarian distress.

\section{References}

Batla Seema, 2008. Regional Dimensions of Inter Crop Diversification in India: Implications for Production and Productivity Growth. Agriculture Situation in India, 64(12): 601-620.

Kebede, E., V.P. Mehta and Dixit, 2000. Diversification of Agriculture in Haryana: an empirical analysis. Agricultural situation in India, New Delhi. 57(8): 459-463.

Korra Vijaya Lakshmi, 2016. Dynamics of Cropping Pattern and Crop Diversification in Amravati Division of Maharashtra. M. Sc. (Agri). thesis, Dr. Punjabrao Deshmukh Krishi Vidyapeeth, Akola.

Kumar, P. and S. Mittal, 2003. Crop diversification in India. Analysis by state and form size group. Agricultural situation in India, 60(5): 273-280.

Kumar, S. and R. Singh, 2013. Crop Diversification in Himachal Pradesh with Special Reference to District Una. J. of Econ. and Social Development, 9(2): $1-14$

Sharma, L. and D.C. Pant, 2008. 
Diversification of cropping pattern through horticulture crops in Rajasthan. Indian J. of Agril. Econ., 63(3): 384385.

Takashi, Kurosaki. 2003. Specialization and diversification in agricultural transportation: The case of West
Punjab. American J. Agril. Econ. 82(2): 372-386.

Yadav, D.B., H.R. Shinde and B.V. Pagire, 2010. The extent and determinants of diversification in the konkan region of Maharashtra state. Indian J. of Agric. Econ., 65(3): 391-392.

\section{How to cite this article:}

Deshmukh, P.S., R.G. Deshmukh, Bhaskar, K.R. 2018. Crop Diversification Remedy on Agrarian Distress. Int.J.Curr.Microbiol.App.Sci. 7(12): 3111-3115.

doi: https://doi.org/10.20546/ijcmas.2018.712.357 